\title{
THE ENCYCLICAL LAUDATO SI' IN THE CONTEXT OF MODERNITY: \\ A VOICE IN THE DIALOGUE ON THE ECOLOGICAL CRISIS ${ }^{1}$
}

\author{
ALBERT FLORENSA \& JOAQUÍN MENACHO \\ IQS (Universitat Ramon Llull)
}

\begin{abstract}
The fact that we live in an interconnected plural world makes it necessary for common problems such as environmental crisis to be solved in common. One of the best ways to accomplish this is through dialogue, the more extensive the better. Plurality, which has plenty of virtues, can also lead to difficulties when defining the conditions of possibility of said dialogue. The present paper wishes to analyze whether the Catholic Church, through the encyclical Laudato Si' by Pope Francis, could be a valid interlocutor in the environmental crisis, specifically in the context of modernity. Can a text written by the highest authority in Catholicism be of interest to others than the believers of this religion and the scholars studying religious phenomena? Do LS's critiques of technoscience imply a rejection of modernity, given that technoscience is an unequivocal part of modern rationality?
\end{abstract}

KEY WORDS: ethics; ecology; modernity; technoscience; Christian Social Thought.

\section{La Encíclica "Laudato Si"» en el contexto de la modernidad: Una voz en el diálogo sobre la crisis ecológica}

RESUMEN: El hecho de que vivamos en un mundo plural e interconectado hace necesario que los problemas comunes, como la crisis ambiental, se resuelvan en común. Una de las mejores maneras de lograr esto es a través del diálogo, cuanto más extenso, mejor. La pluralidad, que tiene muchas virtudes, también puede llevar a dificultades al definir las condiciones de posibilidad de dicho diálogo. El presente trabajo desea analizar si la Iglesia Católica, a través de la encíclica «Laudato Si» del Papa Francisco, podría ser un interlocutor válido en la crisis ambiental, específicamente en el contexto de la modernidad. ¿Puede un texto escrito por la máxima autoridad del catolicismo ser de interés para otros, aparte de los creyentes de esta religión y los eruditos que estudian los fenómenos religiosos? ¿Las críticas de LS a la tecnociencia implican un rechazo de la modernidad, dado que la tecnociencia es una parte inequívoca de la racionalidad moderna?

PALABRAS CLAVE: ética; ecología; modernidad; tecnociencia; Pensamiento Social Cristiano.

\section{LaUdato Si’́ and MOdERnity}

\subsection{Ecology and modernity}

French sociologist Pierre Charbonnier claims that it is necessary to analyze the different ecological proposals regarding modernity, because some of them are overtly opposed to this current. Charbonnier sees in this opposition a threat to all benefits that modernity has brought us.

1 This article has been written thanks to a grant from the Càtedra Ethos Ramon Llull.

This article is part of the research project: "The human condition before the challenges of ecology» of the Francisco José Ayala Chair of Science, Technology and Religion of the Universidad Pontificia Comillas (2016-2019). 
The sociologist classifies the critiques to modernity into two kinds: a) those that consider that modernity should be abandoned, because it has led the societies that have embraced it "towards a moral and political catastrophe» (Charbonnier, 2015, p. 132); b) those that state that modernity is «a period that belongs within its full rights to the course of history, which has its reasons and its motives, and that its possible pathologies have to be treated as social incidents» (Charbonnier, 2015, p. 132).

It can be agreed with Charbonnier that giving up on modernity would be a serious mistake, because some of its benefits in terms of freedom and welfare are undeniable. However, one must be very careful not to make of the characteristic elements of modernity a set of dogmas that cannot be improved, nuanced, and by no means criticized. The lights of modernity have been accompanied by shadows that have to be denounced, as they deprive human beings from essential aspects for their full development.

Finally, one could argue that modernity has fallen behind and that we are now in a different period called "postmodernity», which philosophers and sociologists strive to define. However, we must point out that the intellectual debate on the validity of this new period is still at some extent based on criterion typical of modernity.

When facing issues like the one set by Charbonnier, it is relevant to consider whether Laudato Si' (from now on LS) is antimodern or not. This question is especially important if our aim is to determine the validity of the participation of the Catholic Church, through Francis Pope and his encyclical LS, in the dialogue on environmental crisis. In order to tackle this matter, two questions are raised. Can a text written by the highest authority in Catholicism be of interest to others than the believers of this religion and the scholars studying religious phenomena? The second question is related to the first one: do LS's critiques of technoscience imply a rejection of modernity, given that technoscience is an unequivocal part of modern rationality?

\subsection{Characterization of modernity}

To answer the first question it is necessary to define modernity. Philosopher Pere Lluís Font gives a synthetic characterization of modernity useful for this purpose. Common features of cultural modernity, which is the one that considers its intellectual aspects, can be summarized in the following elements: emancipation as a goal, i.e. personal freedom and autonomy; rationality in its different forms, especially those characteristic of technoscience; and secularization. Three kinds of secularization are distinguished: «(1) a negative one: secularization as the elimination of religion (= secularism); (2) an ambivalent one: the loss of social weight of religious institutions; and (3) a positive one: autonomy of the different cultural spheres, which are independent of each other and emancipated from theological tutelage.» (Font, 2016, p. 30)

Although there are currents within modernity that argue the death of God and abolition of religions, it is not necessarily implied that modernity defends 
such thesis - especially in the case of Christianity. In fact, many of the modern critiques towards religion may be defended by Christianity itself. Emancipation, reason, and autonomy are part of the Christian message - the God of Jesus of Nazareth is a freeing God, and "Christianity may only have a positive outlook on the human efforts to achieve emancipation from all oppression and to set the basis of personal autonomy» (Font, 2016, p. 34). Christianity is the religion of Lógos (cfr. Font, 2016, pp. 17 and 34), and it is therefore obvious that it should not stand against reason. If secularization implies respecting the autonomy of the different cultural and social spheres — and not the desire to eliminate religion-, Christianity will not reject secularization because it will be placed where it belongs. Similarly, the principles of the French Revolution -Freedom, Equality, and Fraternity - are unequivocally evangelical. Besides, Christianity allows the possibility to rationally understand the world with its concept of creation, because «in contrast to, for example, an emanationist conception, the idea of [Christian] creation claims that the world is not divine. Consequently, it affirms that it is possible to apprehend it with our limited human concepts, and that it possesses its own nature and laws.» (García, 2001, p.15).

However, we must admit that at times the evangelical message has been subverted, becoming belligerent against some or all key features of modernity. Critical receptivity is the best stance that modernity and Christianity can take in order to have a fruitful relationship (cfr. Font, 2016, p. 38). Ultimately, Christianity has to become inculturated within the context of modernity for this relationship to take place.

At the same time, modernity has to allow this dialogue to happen. It has previously been pointed out that within this current there are different positions towards the scope of religion, which range from the rejection of secularism to its acceptance. We must remember that this acceptance requires the autonomy of the different cultural spheres.

\subsection{LS, knowledge, justice, dignity, and autonomy}

Positivism denies the validity of statements that do not come from experience or that do not belong to the formal logico-mathematical scope. It raised scientific mathematical knowledge practically to the category of undebatable truth. Different subsequent epistemological currents, without questioning the validity of scientific knowledge, have placed its value below these expectations by nuancing its relationship with the truth and by limiting it to a scientific scope. Simultaneously, other forms of knowledge are recovered. These scopes of knowledge are always autonomous from each other, but they are clearly interinfluenced. One must not be surprised therefore that the so-called tensions between theology and science have faded - and that, for example, there are conferences in which dialogue between theology and science is normally carried out.

LS expresses respect for modernity when it claims that «theological and philosophical reflections on the situation of humanity and the world can sound 
tiresome and abstract, unless they are grounded in a fresh analysis of our present situation» (LS 17). Although it does not possess the critical apparatus characteristic of a scientific text, the first chapter of LS shows plenty of elements of the scientific work on the environmental status of our planet. Elements such as pollution, climate change, water issues, and the loss of biodiversity are discussed. The analyses and proposals of LS are not hollow, but based on scientific data about the world status.

Similarly, the first chapter of the encyclical establishes a relationship between the decline in quality of life and social degradation with the environment, and denounces the attack it implies on the dignity of the people: «human beings too are creatures of this world, enjoying a right to life and happiness, and endowed with unique dignity. So we cannot fail to consider the effects on people's lives of environmental deterioration» (LS 43). The issue of inequality that affects humanity is also pointed out. There is a clear defense of the universality that every approach has to adopt when facing the ecological problem: «inequity affects not only individuals but entire countries; it compels us to consider an ethics of international relations. A true "ecological debt" exists, particularly between the global north and south, connected to commercial imbalances with effects on the environment, and the disproportionate use of natural resources by certain countries over long periods of time» (LS 51). Therefore the dignity, autonomy (expressed as the right to happiness, understood as plenitude), and universality shown in LS prove that this text is aligned with the anthropological principles of modernity.

\subsection{LS, ethics, and dialogue}

Finally, in the context of ethics there is also common ground within the relationship between Christianity and modernity. Modernity seeks universal principles to guide moral behavior, and it is possible for said principles to coexist with specific principles like the ones proposed by Christianity - which, obviously, may only be accepted by the followers of this belief. As explained below, the analysis that distinguishes between ethics of minimums and ethics of maximums allows us to confront this issue.

Adela Cortina asserts the existence of civil ethics, which «consists on a minimum of values and norms shared by the members of a modern society, whichever their religious, agnostic, atheistic, philosophical, political, or cultural beliefs are. This minimum leads them to understand that the coexistence of different conceptions is productive, and that each individual has the right to carry out their happiness projects - as long as it does not impede others from carrying out theirs. This is the reason why we consider civil ethics as a modern ethics of minimums» (Cortina, 2005, pp. 37-38). Ethics of minimums allows us to live together while protecting and promoting autonomy, justice, politics and its institutions. Instead, ethics of maximums is concerned about the dimensions of plenitude. Ultimately, it refers to the dimensions of meaning - or, at least, the search for meaning. Ethics of maximums expresses the particular values that 
man discovers during the search for meaning. Therefore ethics of maximums is essential for human life in a personal dimension. It goes without saying that there is a relationship and a dialogue between the two ethics.

Ethics of maximums should not be hidden, but it should not be imposed either. It should not be an object of indoctrination, but sharing it is important because it is the only way for plurality to become a virtue. The active tolerance introduced by Cortina promotes dialogue and not ostracism, community and not individuality. Ethics of maximums, besides supporting ethics of minimums, may also enrich it by being a source of inspiration for new contents - as the contents of ethics of minimums are unlimited, and they may evolve and grow. A clear example of such dynamic character may be found in the so-called Human Rights, which are key to ethics of minimums. It is essential to understand why it is called the Universal Declaration of Human Rights, and not the Universal Declaration of the Human Rights. From the beginning, the contents of this declaration were not considered to be static, but thought to evolve and grow. Therefore, there are different generations of Human Rights, and there is a continuous debate on its extension.

In its proposals, LS shows characteristics of ethics of minimums, but also others typical of ethics of maximums resulting from the Christian experience - which, as argued above, may have a positive effect provided they are not imposed. Hence, when LS claims that there are limited technical solutions to face environmental crisis, at the same time it points out certain actions that belong in a non-exclusive way to a Christian conception of the world. Examples of said actions are the following: "when cooperatives of small producers adopt less polluting means of production, and opt for a non-consumerist model of life, recreation and community. (...) Or indeed when the desire to create and contemplate beauty manages to overcome reductionism through a kind of salvation which occurs in beauty and in those who behold it» (LS 112). Similarly, LS quotes John Paul II «man too is God's gift to man. He must therefore respect the natural and moral structure with which he has been endowed» (John Paul II, 1991; in LS 115). LS also quotes Guardini, pointing out that the modern man has ended up placing technical reason above reality, because this man «sees nature as an insensate order, as a cold body of facts, as a mere "given", as an object of utility, as raw material to be hammered into useful shape» (Guardini, 1981; in LS 115). In the last two examples, the encyclical provides specific points that may contribute to the dialogue on the reasons of the environmental crisis.

Kant was one of the key authors in modern moral philosophy thanks to his proposal of a formal and universal ethics. The Prussian philosopher sets the bases of human dignity in moral autonomy, which feeds on reason. With the same purpose, but focusing on collective reason rather than on individual reason, K.O. Apel's and particularly Jürgen Habermas's discursive ethics search for a norm of ethics through dialogue. The right and the ability to participate in moral dialogue become essential. Cortina supplements the Habermasian proposal by adding to the rational discourse a "cordial» dimension which is 
not considered in Habermas's approach: «It is true that communication, in order to happen, requires a common understanding, but it also needs an ability to love values. It does require argumentation techniques, but said techniques have to be possessed by a character equipped with the virtues necessary for serious dialogue. It cannot happen without argumentative aptitudes, but neither without being receptive enough towards narrations, testimonies, and life stories. It also needs to count on a profound sense of justice, a determined will of justice, which emanates from the experience of compassion. We know justice not only through reason, but also through our hearts» (Cortina, 2009, p. 221). Therefore, the product of moral dialogue is more complete, because it adds axiological and affective components to rationality. Such components are inherent to human beings, particularly to moral phenomenon.

LS's infallible commitment to dialogue exposes a common ground between the encyclical and the ethical bases accepted by modernity. Said commitment is shown from the introduction of LS, firstly by thanking the task of «all those striving in countless ways to guarantee the protection of the home which we share» (LS 13), and also by recognizing that "outside the Catholic Church, other Churches and Christian communities - and other religions as well have expressed deep concern and offered valuable reflections on issues which all of us find disturbing» (LS 7). Later, it demonstrates its unquestionable commitment to dialogue: "we need a conversation which includes everyone, since the environmental challenge we are undergoing, and its human roots, concern and affect us all», and adds that "we require a new and universal solidarity» (LS 14). LS even denounces those interventions carried out without being backed up by "policies developed and debated by all interested parties» (LS 183). Moreover, when referring to genetically modified organisms (GMOs), it claims that «discussions are needed in which all those directly or indirectly affected (farmers, consumers, civil authorities, scientists, seed producers, people living near fumigated fields, and others) can make known their problems and concerns, and have access to adequate and reliable information in order to make decisions for the common good, present and future» (LS 135). Being committed with dialogue means accepting surprise, i.e. the recognizing that the other may bring valuable contributions which one has not thought of - and therefore admitting that one is not omniscient. But it is at the end of this introduction where we can find words that, in the author's opinion, stress the will for dialogue that motivates the Pope's discourse. When referring precisely to the contributions based on the Christian experience that LS shows, Francis presents them as an offering: «finally, convinced as I am that change is impossible without motivation and a process of education, I will offer some inspired guidelines for human development to be found in the treasure of Christian spiritual experience» ${ }^{2}$ (LS 15). The Bishop of Rome offers — does not oblige or impose-, because he knows that the treasure - i.e. the most essential

\footnotetext{
2 Emphases added.
} 
element in Christianity, which consists on the experience of a Loving God committed with all men and women - can only be offered, never imposed. This is the offering, made from a perspective of sense and fullness - and hence particular- that Francis brings to universal dialogue. Therefore the will for dialogue defended by LS is made clear.

It must also be succinctly pointed out that LS is concerned about future generations, similarly to a good part of modern philosophy dedicated to the ecological problem ${ }^{3}$ : «we can no longer speak of sustainable development apart from intergenerational solidarity» (LS 159). Besides, LS's consideration of the cordial aspects in ethical dialogue are also remarkable: «it is essential to show special care for indigenous communities and their cultural traditions. They are not merely one minority among others, but should be the principal dialogue partners, especially when large projects affecting their land are proposed. For them, land is not a commodity but rather a gift from God and from their ancestors who rest there, a sacred space with which they need to interact if they are to maintain their identity and values» (LS 146).

Finally, one must emphasize the space dedicated in LS to the practice of dialogue, mainly in the chapter that describes the lines of orientation and action. LS claims that "a global consensus is essential for confronting the deeper problems, which cannot be resolved by unilateral actions on the part of individual countries» (LS 164), which is why it proclaims the need to continue and foster the dialogue on the environment in international politics. However, it is not only about international dialogue - dialogue within a country or a community has to be invigorated in order to promote new state and local policies. LS demands transparency in dialogues, which is why it requests the empowerment of all parties involved in them — as shown above when discussing GMOs - because, precisely, «participation (...) also entails being fully informed about such projects and their different risks and possibilities (...). Honesty and truth are needed in scientific and political discussions; these should not be limited to the issue of whether or not a particular project is permitted by law» (LS 183).

Therefore, all the aforementioned features present in LS in regards to discursive ethics also reveal a commitment of the encyclical with modernity particularly with its practical philosophy.

In conclusion, one must affirm that LS agrees with modernity: rationality, autonomy of human beings, and autonomy of knowledge - together with other characteristics of modernity - are not only tolerated in this encyclical, but also defended and fostered. Nevertheless, there is a specific point that is important to remark. Despite the fact that LS makes a general recognition of technoscience, and scientific knowledge is applied in the encyclical, LS also sharply critiques technoscience - particularly condemning the excessive influence the

3 As an example we quote JonAs, H. (1995), El principio de la responsabilidad (Javier Fernández, tr.). Herder, Barcelona (Original work published 1979) 
technocratic paradigm has on man. Given that science and technique are key elements of modernity, will this critiques invalidate everything we have defended so far? One of the conclusions of the encyclical places the roots of current humanity problems - amongst which stands the environmental problem-in «the direction, goals, meaning and social implications of technological and economic growth» (LS 109). Does this conclusion expel LS from modernity?

\section{LS'S CRITIQUES TO TECHNOCRATIC PARADIGM}

\subsection{Science, technique, technology, and technoscience}

Firstly, it must be advised that elaborating a rational critique is characteristic of modernity, even if the objects of such critique are key elements of modernity such as science and technique.

Given that LS does not offer definitions of the concepts of science and technique, this must be done in order to subsequently analyze the critiques made by the encyclical.

In a first approach, following Evandro Agazzi, science could be defined as an area of knowledge that possesses two characteristics: accuracy and objectivity. While accuracy refers to the criteria demanded by each particular science in order to justify the propositions made in its field, objectivity — understood as intersubjectivity - aims to enable, amongst others, public discourse and subject independence. Without intending to invalidate Agazzi's definition, we must analyze more in depth what science is in order to evaluate the critique made by LS. To this purpose, we consider it necessary to briefly go through the beginnings of modern science.

The birth of modern science occurred during the scientific revolution, which took place between the $16^{\text {th }}$ and the $18^{\text {th }}$ centuries. Before modern science, occidental knowledge of nature was essentially based on the procedures of Greek philosophy, and was carried out in good part through contemplation (theoria) and natural language. This type of knowledge did not use mathematics or experimentation as modern science does. Therefore, Gilbert Hottois claims that ancient science «is linguistic, semantic, speculative, and offers a view of the world which makes sense but that, at the same time, is not fully operational» (Hottois, 1991, p. 15). In contrast, modern science implies experimentation, which provokes phenomena, isolates objects of study, frequently uses a technical deployment, and makes a mathematical model of reality. As a consequence, «it offers an effectiveness in the form of ability of prediction and power over reality which humans had never possessed before» (Florensa, 2016, p. 204). For this reason, one must not be surprised when LS claims that the procedure of modern science «in itself is already a technique of possession, mastery and transformation» (LS 106). This implies that modern science, considering its effectiveness and its 
experimental method, may never be qualified as axiologically neutral due to its ability of action over the world.

Regarding technique, a very common definition is again offered by Agazzi: "accumulation of operational procedures useful from a practical point of view with the aim to achieve particular goals. Usually, findings are verified and improved through the experience of many generations and constitute a knowhow (to do certain things), without necessarily implying knowing why (they are done like this)» (Agazzi, 1996, p. 97). However, with the development of technique associated with scientific progress, the word «technique» is often reserved to refer to a simple know-how, and the word «technology» is used to refer to a set of more complex techniques which demand a close relationship between science and technique. Consequently, one must not be surprised of the fact that the understanding between modern science and technique is so intimate, as they both share a common goal - effectiveness. This is the reason why it is often difficult to distinguish between science and technology, and therefore some authors use the word «technoscience» to refer to the scientific and technological activities in general. The term «technoscience» appears in LS $(103,107)^{4}$, which proves that the encyclical is fully aware that science and technique share effectiveness as a key feature. Another definition of technique that could help us in the analysis of LS is offered by Jacques Ellul: «Technique [is] constituted by the set of most effective means at a certain point. (...) In other words, wherever we can find research and application of new means following the criteria of effectiveness, one must say that Technique is present» (Ellul, 1977, p. 34). Finally, it must also be stated that the terms «technique» or «technical» may also refer to the technical capacity that human beings possess (in all senses: technique, technology, technoscience), together with the set of products which originate from this capacity. In this case, we are talking about the technical phenomenon.

As one can infer from reading LS, the encyclical is not very systematic when using the terms defined above. However, the reader may interpret without major issues which sense is being used depending on the context. Given that the present paper refers to the content of LS, we must make the same exercise of interpretation.

\subsection{The submission of man to technoscience: the technocratic paradigm}

After quoting John Paul II and Benedict XVI praise science and technique as products of human creativity which allows us to escape the constrictions of nature, LS mentions and thanks the fruits of technique: «technology has

4 The word «technoscience» appears in all versions of LS103 we've gone through. However, in LS 107, it appears in the Spanish, French, Italian and Portuguese versions, whereas it doesn't appear in the German and English versions. Be as it may, we think that the terms that substitute «techno-science» in the German and English versions are in fact equivalent to said word. 
remedied countless evils which used to harm and limit human beings. How can we not feel gratitude and appreciation for this progress, especially in the fields of medicine, engineering and communications? How could we not acknowledge the work of many scientists and engineers who have provided alternatives to make development sustainable?» (LS 102). Similarly, referring to the issue of GMOs, the encyclical claims that «a broad, responsible scientific and social debate needs to take place» (LS 135). Therefore, there is no doubt that LS recognizes the beneficial part of technique and its value when it comes to making decisions. It is very important to highlight this fact, because it shows that LS does not question science and technique in an absolute way. LS does not critique technoscience itself - that would be absurd, given the fact that research for knowledge as well as technical ability and activity are features of human beings. Instead, the critique is pointed at the relationship that human beings maintain with science and technique. Hence, while placing the roots of ecological crisis on humanity, LS suggests thinking about «the dominant technocratic paradigm and the place of human beings and of human action in the world» (LS 101). "Technocratic paradigm» refers to the set of values and the world view deducted from technique - research of means that bring maximum effectiveness at a certain point-, and science - understood as possession, domination, and transformation. The technocratic paradigm also shows that technoscience has become a system - it is no longer formed by a certain technique or another, or a certain scientific field or another. Instead, it is now a scheme that can only be understood in its entirety due to the fact that all its elements are interconnected. As a consequence, in order to face the issues derived from the technocratic paradigm, the solutions have to consider the system in its entirety as well as the influence of the paradigm in the configuration of values and virtues of people and societies that live under the influence of this model.

However, the most severe problem occurs when societies give in to this «undifferentiated and one-dimensional paradigm» (LS 106), subduing the totality of human life to the requirements of this model. Then, the world becomes "completely open to manipulation» (LS 106). Hence, although man has always needed to intervene in the world to live, history proves that those civilizations which have not been considerate with nature and have not maintained a respectful (not submissive) relationship with it have eventually disappeared ${ }^{5}$. For this reason, LS warns us that since human beings gave in to the values and world view characteristic of the technocratic paradigm, their interest has become to obtain everything possible from the world with the imposition of their hand, «while frequently ignoring or forgetting the reality in front of us» (LS 106). The convenient disappearance of Aral Sea or the severe effects of

The following book covers the relationships maintained by different societies with environment throughout time: Diamond, J. (2009), Colapso (Ricardo García, tr.). Debolsillo, Barcelona (Original work published 2005) 
atmospheric pollution are good examples of this ignorance. It must be pointed out, as LS does, that a good part of philosophy and sociology, even if they do not specifically use the concept «technocratic paradigm», have denounced the havocs of the hegemony of technoscience. Therefore, LS does not elaborate an isolated critique. Instead, it adds up to the critiques made from modernity to these events, while bringing its own Christian view. LS does not oppose to reason, but to the absolutization of a type of reason - instrumental reason. Said absolutization is present in deferent spheres. On the one hand, it can be found in the excessive specialization of studies, which allows big progress in very specific matters, but it also leads to a loss of «appreciation for the whole, for the relationships between things, and for the broader horizon, which then becomes irrelevant» (LS 110). On the other hand, and as a consequence of this loss, man finds it very difficult to find solutions to global problems such as the environmental crisis, but also inequality and poverty. As a conclusion, the hegemony of instrumental reason hinders the thought directed to ethical or philosophical questions in general. Then, «life gradually becomes a surrender to situations conditioned by technology, itself viewed as the principal key to the meaning of existence» (LS 110). According to the encyclical, this conditioning implies effects such as superficiality, "environmental degradation, anxiety, a loss of the purpose of life and of community living» (LS 110). Such effects have been pointed out in various ways by contemporary authors, e.g. Zygmunt Bauman and Byung-Chul Han.

\subsection{Technoscience - a matter of power}

In fact, LS claims that "humanity has entered a new era in which our technical prowess has brought us to a crossroads» (LS 102). And it adds: «never has humanity had such power over itself, yet nothing ensures that it will be used wisely, particularly when we consider how it is currently being used» (LS 104). The encyclical warns us that this power is in hands of a small part of humanity, and the increase of such power is not necessarily good and does not imply progress. In order to reinforce this point, the encyclical relies on Romano Guardini, who doubts the ability of modern man to manage this power. According to Guardini, human being is not «suppressed by any regulation that restricts freedom, but only by the supposed imperatives of utility and safety» (Guardini, 1981, p. 94). He adds: «the main problem around which the cultural task will spin in the future, and on the solution of which everything will depend - not only welfare and misery, but also life or death — is the problem of power. The problem is not in the increase of power, which operates by itself, but in its restraint, in its correct use» (Guardini, 1981, pp. 101-102).

Ellul also affirms that the problem of technique is a problem of power. Therefore when the French thinker proposes an ethical model for a society living in a technical environment, he makes of non-power an essential element - not everything that can technically be done needs to be done. He claims we must suppress the technical imperative that obliges us to do everything technically 
possible. Ellul claims that it is necessary to avoid technical power the same way that we avoid tyranny and the concentration of legislative, executive, and judicial powers in the same hands - in order for political power to be a tool in favor of human freedom and plenitude. One must think that «the power of technique is so great that it even makes it difficult for us to create feelings that alert us from its harmful and unfair effects for those who are further away in space and time from us, and for the environment» (Florensa, 2016, p. 207).

However, the point is whether human beings can have control over this power - ultimately, whether they can be free. Firstly, LS recognizes that the technocratic paradigm «has become so dominant that it would be difficult to do without its resources and even more difficult to utilize them without being dominated by their internal logic» (LS 108), which is why it makes it impossible to live in ways that are not subject to its requirements. This shows the universalizing character of technique, which aims to encompass all spheres of human life from politics and economy to the most intimal areas such as interpersonal relationships - and even religion. In this context, it appears that the technocratic paradigm has ultimately expelled everything that could complicate its development, and therefore any possibilities of control over the power that controls and guides this paradigm have been suppressed.

With this denunciation, LS is ultimately questioning human freedom. If the power of technoscience frees us from the constraints of nature, now humans have to free themselves from the power of technoscience. Clearly, the defense of human freedom and the critique towards the forces that limit it -and therefore hinder human autonomy - prove again that the encyclical belongs to modernity.

Therefore, it is not an attack against technoscience but a defense against technoscientific power, which aims to completely colonize human life. It is true that in the past certain powers such as natural, political, economic, or religious powers conditioned human life - and some of them still do. However, now one of the main agents is technocratic power. In the same way that Christianity denounced the aforementioned powers in the past, now it is time to report the absolutization of the technocratic paradigm and to develop offers of freedom from its tradition. That is exactly what LS offers us, thanks to its inculturation within modernity and its proposals to suppress the shadows and excesses of this current.

\section{Conclusions}

As a conclusion, the answers to the questions raised at the beginning of the article will be summarized. It is clear that the discourse of LS is relevant in the context of modernity. This is due to the values supported by the encyclical, as well as its offering to be another voice in the ethical-environmental dialogue. Similarly, the critical analysis conducted by LS on technoscience has two 
features: 1) it is not opposed to technoscientific rationality, but instead it recognizes its utility; 2 ) it denounces the absolutization of such rationality, which tends to monopolize all axiological fields with severe practical consequences. However, such denunciation does not imply an antimodern position - as the present paper tried to prove-, but it belongs to the modern currents that foster the evolution of modernity while facing contemporary challenges.

\section{BIBLIOGRAPHY}

Agazzi, E. (1996). El bien, el mal y la ciencia. Las dimensiones éticas de la empresa científico-tecnológica (Ramón Quraltó, tr.). Madrid: Tecnos. (Original work published 1992).

Charbonnier, P. (2015). «Jacques Ellul ou l'écologie contre la modernité», Ecologie \& politique, 50, pp. 127-146.

Cortina, A. (2005). Ética de la empresa. Madrid: Trotta.

Ellul, J. (1977). Le système technicien. Paris: Calmann-Lévy.

Florensa, A. (2016). «La raíz antropológica de la crisis ecológica: el hombre y la tecnociencia», Revista de Fomento Social, 71, pp. 203-209, Córdoba.

Font, P. (2016). Cristianisme i modernitat. Per una inculturació moderna del cristianisme, Fundació Joan Maragall, Barcelona.

García, M. (2001). El dialogo teologia-ciencias hoy. I. Perspectiva histórica y oportunidad actual, Institut de teologia fonamental, Sant Cugat del Vallés.

Guardini, R. (1981). El ocaso de la Edad Moderna. (Jose María Valverde, tr.). Madrid: Ediciones Cristiandad. (Original work published 1950)

Hottois, G. (1991). El paradigma bioético. Una ética para la tecnociencia. (M. del Carmen Monge, tr.). Barcelona: Anthropos. (Original work published 1990)

Pope Francis (2015). Encyclical Letter Laudato Si'.

Pope John Paul II (1991). Encyclical Letter Centesimus annus.

Universitat Ramon Llull

albert.florensa@iqs.edu

Universitat Ramon Llull)

joaquin.menacho@iqs.edu
Albert Florensa, IQS

Joaquin Menacho, IQS

[Artículo aprobado para publicación en enero de 2019] 